\title{
DEVELOPING ENGLISH READING MATERIALS BASED ON LOCAL CONTENT FOR GRADE TENTH STUDENTS OF SMAN 10 MEDAN
}

\author{
Esra Sigalingging, Kammer Tuahman Sipayung \\ HKBP Nommensen University \\ Esrauliarta@gmail.com
}

\begin{abstract}
This study dealt with the development of English Reading Materials of Senior High School in SMAN 10 Medan. The objectives of this study is to develop the English reading materials for students of SMAN 10 Medan which represent the characteristics of their sociocultural environment. The research was conducted at SMAN 10 Medan. The research procedures of this study were Research and Development (R \& D) that were done through three phases: 1) evaluation and need analysis, 2) materials design, and 3) materials Validation. The instruments used in this research were documentary sheet, questionnaire sheet and interview sheet. The data from evaluation and need analysis were analyzed by using descriptive technique and the data from expert judgement result were analyzed using quantitative data analysis. The result of this study was a course book of local content-based reading materials which consist of 3 genres: recount genres, descriptive genres, and narrative genres, in which each genre consists of 2 texts complete with the tasks or exercises. Based on the experts' judgement results, the score was 87.06 which belonged to good category baesd on Dirgeyasa (2011), since the range is (70-89).
\end{abstract}

Keywords: English reading materials, Local content-based materials, Research and Development

\section{Introduction}

Localizing the English reading materials will be the best solution. Dar (2013) proposes the localizing learning materials will present cultural values related to each area where the students live so that the students can easily identity and relate to. Localizing English reading materials can be implemented by using local content. According to Maryono (2016), local content in teaching is an activity to develop competencies that are adjust to the characteristics and potency of a region, including the area excellence. Local content material will help the students to be active and feel confident in the class, as what they are learning is something they are familiar with.This study will focus on developing English reading materials (the text and exercises) based on local content can make students easier and more interest in learning English. These new English reading materials will be totally different with existing one, because the topics are much more familiar to the students so they will be more active in the learning process as what they are going to learn is something that they can easily relate to. In addtion, the materials will also be prepare in accordance with the English reading basic competencies that has set by the educational government. As Sahlan (2017:2) states reading is the recognition of printed or written symbols which serve as stimulative to the recall of meanings built up through the reader's past experience.

Definition of the local content, Maryono (2016:895) proposes the local content is a curricular activity to develop the competencies that are adjust to characteristics and potential of the region, including the area excellence. His further argues that local content in the curriculum can stan alone as alone as a subject, the local content has its own time allocation. 
While as a subject of study materials, the local content is the additional study in the materials will be based on local content as a subject in the materials that already exist. The local content is a part of the structure and the curriculum's content on the Content Standards in Education Unit Level KTSP Curriculum (The Degree of the Republic of Indonesia No. 22 of 2006 on the Content Standards) as well as the curriculum in 2013 (The Degree No. 32 of 2013 on the National Standards).

The purposes of the implementation of the local content is to equip the students with the attitudes, knowledge, and skills necessary to (a) know and love the natural, social, cultural, and spritual environment in the region; and (b) preserve and develop excellence and knowledge areas in order to support national development. So, the writer conclusion is a subject in the materials that already exist to develop the competencies by the education unit and not limited to the subjects of skills.

Types of local content are arts and culture; crafft; physical education, sports and health; language; and technology. In Maryono (2016) state that, thelocal content includes two of types of local content. There are:

1. Local content of the circumstances and the needs of the region. That is, the are is all things that are in certain areas which are basically related to the natural, socio-economic, and sociocultural environment. The needs of the area everything needed by the people in an area, in particular for the survival and improvement of people's lives, who adapt to the development direction of the area as well as the potential of the areas concern. The region needs are: (1) preserving and developing the cultures of the areas; (2) improving the ability and skills in specific areas, related to the local economy; 3) enhancing the mastery of the English Language for everyday purposes, and to support individuals undergoing further learning (the long life education); (4) incerasing the ability of entrepreneurship.

2. Local content can be: the local language, local arts, local handy craft, custom, and the various characteristics of knowledge and the surrounding natural environment, as well as the things that are considered necessary by the regoions concerned.So, local content consider necessary by the regions concern.Local content must be given to the primary and secondary education, both in general education, and vocational education or special education, some possible curriculum in all regencies or cities within a province, especially in SMA / MA / SMK.

Maryono (2016) explains some stages used to develop the materials by using the local content, they are:

1. The analysis of the context of the natural, social, and or cultural environment.The identification of the local content.

2. The formulation of the basic competence in relevant learning cargo.

3. The determination of the appropriate level of the education unit for each basic competence.

4. The integration of the appropriate level in relevant learning cargo.

5. The determination of local content as a part of the payload of learning or being a stand-alone subject.

6. The preparation of the syllabus andtextbooks. As Kammer (2018:121) states Principle of Language Learning and Teaching textbook as the object of investigation as it is widely used in language teaching particularly for the teaching.

In line with the steps proposes by Maryono above, the writer conclusion used some steps in developing the English reading using the local content in Medan:

1) Identifying the basic competencies of English reading for grade ten students.

2) Identifying the local content in Medan and matching it to the English reading basic competencies. 
3) Formulating the objectives of study.

4) Writing the reading texts with the taska or exercises relate to each topics.

Before designing materials, the material developer are suppose to do an analysis called the needs analysis. Need analysis procedures used to collect information about learners' need (Richard, 2001:51).In discovering needs, there are aspects that must be discovered. As Hutchinson and Waters (1987:58), they are:

1. Necessities (what the learner has to knowto function effectively),

2. Lacks (what the learners knows and does not know already),

3. Wants (what the learners' think they need).

Hutchinson and Waters (1987:54) divide needs into target needs (what the learner needs to do in the target situation) and learning needs (what the learner needs to do in order to learn).

1) Target Needs

Hutchinson and Waters (1987) states that analysis to target needs can look at:

1. Necessities: the type of need determine the demands of the target situation, that is, what the learner has to know in order to function effectively in the target situation.

2. Lacks: lacks means what the learner know already, so that teacher can then decide which of the necessities of learner's lacks.

3. Wants: what do the learners wish to learn? It its subjective needs.

2) Learning Needs

In analysing learning needs, some questions can be used, proposes by Hutchinson and Waters (1987:62), which are: 1) Why are the learners taking te ciurse?, 2) How do the learners learn?, 3) What resources are available?, 4) Who are the learners?, 5) Where will the ESP class take place?, 6) When will the ESP class take place?. Hutchinson and Waters (1987) proposes a number of ways that are frequently used in analysing needs, namely questionnaires, interviews, observations, and data collections.

This research focus on developing English reading materials for grade ten students of SMAN 10 Medan based on the local content in the town. The topics in the texts are adjust to the basis competencies in the syallbus. From the basic competences, it is know that there are three genres learn by the grade ten students, namely descriptive, recount, and narrative.it is states in the basic competences that the topic of the descriptive genre is about places of interest and well know historical places, and the topic for recount genres is sbout the historical events, while the topic for narrative genre is about the legend. Considering the local content of Medan.

Method

The subjects of this research are students at grade ten of SMAN 10 Medan. The English teacher is the one who knows the students well. So, in this research, the teacher will ask about the need of the students, as well as their interest in learning English through the interview. In addition, the questionnaire sheets also give to students. There are 3 English teachers at the school. However, the subjects of this research has only the teacher who teach in X IPA 3. There are 6 classes of grade ten students in SMAN 10 Medan. They are divided into 3 classes for science class and 3 classes for social class. However, the subject of this research has only for X IPA 3 which consists of 36 students. It is by using random sampling.

Technique of data collections correspondent to the instrument of data collection. There are three techniques of data collection in this research, they are documentary technique, questionnaire technique, and interview technique. There are three instrument of data collections, they are documentary sheet, questionnaire sheet, and interview sheet.

1. Documentary sheet is used to collect the data, the collect the data from write 
resources such as existing materials and existing syllabus.

2. Questionnaire sheet. There are three kinds of questionnaire sheet in this research.

The first isquestionnaire for materials evaluation. It is give to students to find out information about the real existing English reading materials used in daily learning process. They are organize under the following categories: aims, design and layout, linguistics features, topics methods of teaching and learning, and the last is skill (Dirgeyasa 2011).

The second is need analysis questionnaire. It aims at finding out the data about students' needs, problems and interest while learning English especially reading comprehension. The need analysis questionnaire in this research is organize under the following categories: students' background, goal, necessities, lacks, wants, and learning needs.

The third questionnaire is the expert judgement questionnaire. It is give to the expert to know whether the materials develop have good, reliable, and valid. It is organize under the following categories: Content, process, linguistic features, and layout (BSNP 2011).

3. Interview sheet. It is do by using interview sheet. Interview sheet is used to collect the dat from the teacher orally. The data get from the interview then transcribe into write from. It aims at finding the more detail information about students' needs, difficulty to achieve learning goals of reading comprehension and the appropriate English reading materials the students.

There are three steps of data analysis by using descriptive technique, they are evaluation and need analysis, designing the materials, and validating by experts.

\section{Finding and Discussion Research Finding}

The data in this research are analyze by using descriptive technique. There are three steps of data analysis by using descriptive technique, they are evaluation and need analysis, designing the materials, and validating by experts.

Step 1. Evaluation and Need Analysis

There are two main activities in this step. The first is evaluating the materials and the second is conducting the analysis.

\section{Evaluation}

This step is to know the learning activity and environment in SMAN 10 Medan as well as to evaluate the existing English reading materials used by the grade ten students. The source of data in are collect by using questionnaire sheets and also documents such as syllabus and existing Englih text book used by the grade ten of SMAN 10 Medan. The data in this step are analyse by using descriptive technique.They covered the following dimension; aims, design and layout, linguistics feature, topic, learning method, and skill. The result of the analysis were described as follows:

1) In terms of aims, the score 2.02 showed that the objective of the existing reading materials was fairly relevant with the objective of the students. Next, the score 1.4 showed that the existing reading materials were not relevant with the learning situation this time, and the score 1.9 showed that the students in learning English especially in reading skill.

2) In terms of design and layout, the score 2.2 showed that the design of existing reading materials in term of structure, function, topic and skill was fairly relevant. The score 1.8 showed that the sequence of existing reading materials were fairly relevant. The score 1.4 showed that the connection between one topic to another in existing reading materials was relevant. The score 2.3 showed fairly relevant that the previous topic in existing reading materials could support the mastering of next topic. The score 1.8 showed that the illustration provided in the existing reading materials were fairly relevant. The score 2.05 showed it was 
fairly relevant that the existing reading materials designed clearly.

3) In terms of linguistic feature, the score 1.3 showed the grammatical used in the existing reading maaterials were less relevant to the students' ability. The score 2.6 showed it was relevant that existing reading materials provided the vocabularies related to the next. Next, the score 1.3 showed it was less relevant that the instruction for the exercisess in the text book could be understood easily by the student. Last, the score 2.2 showed it was fairly relevant that the exercises provided in the existing reading materials could increase students' understanding towards the text.

4) In terms of topic, the score 0.4 showed it was less relevant was interesting for the students. The score 1.3 showed it was less relevant that the topic in the existing reading materials were appropriate to the students' ability. The score 1.2 showed it was less relevant that the topic in the existing rrading materials could make the students learn English actively. Last, the score 0.4 showed it was not relevant the topic in the existing reading materials were appropriate to students' sociocultural environment background.

5) In terms of learning method, the score 2.1 showed it was fairly relevant that learning method used daily teaching and learning process was appropriate to the existing reading materials. The score 2.3 showed it was fairly relevant that the learning method used in daily teaching and learning process was appropriate to the students' ability. The score 1.4 showed it was less relevant that the learning method used in daily teaching and learning process could motivate the students to learn English. The score 0.9 showed it was not relevant that the learning method used in daily teaching and learning process could make the students active in learning English. The score 2.1 showed it was fairly relevant that the learning method used in daily teaching and learning process was based on local content.
6) In terms of skill, the score 1 showed it was less relevant that the existing reading materials could be integrated with another skills. Last, the score of 1.4 showed it was less relevant that thr exisiting reading materials could help the students to improve their reading skill.

Based on the result of materials evaluation described above, it was concluded that the existing reading materials need to develop as it was less relevant with the need of the students.

\section{Neeed Analysis}

This step is conduct to know the appropriate English reading materials needed by the grade ten students of SMAN 10 Medan and the teacher as well. In this step, the sources of data are the students and also the English teacher. The data in this step are collect by using documentary sheet, questionnaire and interview sheet. The data are analyse by using descriptive technique.

The result of the need analysis, the need of the students were described in detail as follow:

1) In terms of students' background, the score 2.3 showed that the students were not really active in using English. Next, the score 0.6 showed that the students' ability in English was not in advanced level and the score 2.5 showed that they were not really often read an English text.

Tabel 1: The Result of Need Analysis in Terms of Students' Background

\begin{tabular}{|c|l|c|c|}
\hline No & \multicolumn{1}{|c|}{ Statements } & Score & $\begin{array}{c}\text { Level of } \\
\text { agreement }\end{array}$ \\
\hline 1 & $\begin{array}{l}\text { I tend to be more } \\
\text { active in using } \\
\text { english }\end{array}$ & 2.3 & Fairly agree \\
\hline 2 & $\begin{array}{l}\text { My English ability } \\
\text { is in advanced } \\
\text { level }\end{array}$ & 0.6 & Not agree \\
\hline 3 & $\begin{array}{l}\text { I often read an } \\
\text { English reading } \\
\text { text }\end{array}$ & 2.5 & Fairly agree \\
\hline
\end{tabular}

2) In terms of goal, the score 3.3 showed that the students agreed that they learn English as their provisions to get te better job in the future. 
Tabel 2: The Result of Need Analysis in Terms of Students' Goal

\begin{tabular}{|c|c|c|c|}
\hline No & Statements & Score & $\begin{array}{c}\text { Level of } \\
\text { agreement }\end{array}$ \\
\hline 1 & $\begin{array}{l}\text { I learn English as } \\
\text { my preparation to } \\
\text { get a good job in } \\
\text { the future }\end{array}$ & 3.3 & Agree \\
\hline
\end{tabular}

3) Necessities mean to find out what the students need function in target situation. The score 2.7 showed that the students agrred that one of the skill they need in learning English was reading.

Tabel 3: The Result of Need Analysis in Terms of Students' Necessities

\begin{tabular}{|c|l|c|c|}
\hline No & \multicolumn{1}{|c|}{ Statements } & Score & $\begin{array}{c}\text { Level of } \\
\text { agreement }\end{array}$ \\
\hline 1 & $\begin{array}{l}\text { One of skill I } \\
\text { need in learning } \\
\text { English is } \\
\text { reading }\end{array}$ & 2.7 & Agree \\
\hline
\end{tabular}

4) Lack meant to find out students' level of proficiency and how much it creats the gap with the target proficiency. In terms of lack, the score 2 showed that the students fairly agreed that they got difficulties in understanding the main idea of an English text. Next, the score 2.6 showed that the students agreed that they got difficulties in understanding the text organization. And finally, the score 2 showed that the students fairly agreed that they they got difficulties in understanding the writers' purpose in writing the text they read.

Tabel 4: The Result of Need Analysis in Terms of Students' Lack

\begin{tabular}{|c|l|c|c|}
\hline No & Statements & Score & $\begin{array}{c}\text { Level of } \\
\text { agreement }\end{array}$ \\
\hline 1 & $\begin{array}{l}\text { I got } \\
\text { difficulties } \\
\text { in } \\
\text { undestandin } \\
\text { g the main } \\
\text { idea of a } \\
\text { reading text }\end{array}$ & $\begin{array}{l}\text { Fairly } \\
\text { agree }\end{array}$ \\
\hline 2 & $\begin{array}{l}\text { I got } \\
\text { difficulties } \\
\text { in } \\
\text { undestandin } \\
\text { g text } \\
\text { organization }\end{array}$ & $\begin{array}{l}\text { I got } \\
\text { difficulties } \\
\text { in analyzing } \\
\text { the writers }\end{array}$ & 2.6 \\
\hline 3 aree \\
\hline
\end{tabular}

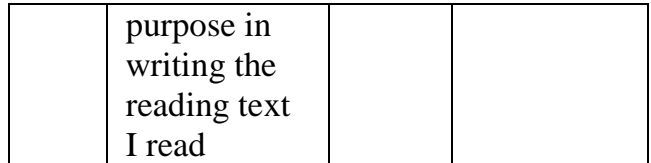

5) Wants meant to find out students' perceptions about what they really need. In terms of wants, the score 3 showed that the students agreed tat they need to master many English vocabularies. Next the score 3 showed that the students agreed that they need the ability to answer the comprehension questions of reading text. Last, the score 2.5 showed that the students fairly agreed that they learned English from the textbook.

Tabel 5: The Result of Need Analysis in Terms of Students' Wants

\begin{tabular}{|c|l|c|c|}
\hline No & \multicolumn{1}{|c|}{ Statements } & Score & $\begin{array}{c}\text { Level of } \\
\text { agreement }\end{array}$ \\
\hline 1 & $\begin{array}{l}\text { I need to master } \\
\text { more vocabularies } \\
\text { in English }\end{array}$ & 3.08 & Agree \\
\hline 2 & $\begin{array}{l}\text { I need the ability to } \\
\text { answer questions } \\
\text { from the reading } \\
\text { text easily }\end{array}$ & 3.02 & Agree \\
\hline 3 & $\begin{array}{l}\text { I learn English from } \\
\text { the English } \\
\text { textbook }\end{array}$ & 2.5 & Fairly agree \\
\hline
\end{tabular}

6) Learning needs meant to find out the knowledge and ability that the learners needed in order to be able to function well in target situation. In terms of learning need, the score 1.8 showed that the students fairly agreed that they had ever read an English text about their environment. The score 3.1 the students agreed that English reading materials in which the topics are related to their sociocultural environment were important to learn. The score 3.8 the students strongly agreed that they were interested in learning English reading materials about ecotourism places in Medan. The score 3.5 showed that the students agreed that they were interested in the learning English reading materials about historical places in Medan. The score 3.5 showed that the students agreed that they were interested in learning English reading materials about historical events from Medan. The score 3.6 showed that the students strongly agreed that they were interested in learning 
English reading materials about the legend from Medan. The score 3.3 showed that the students agreed that they were interested in learning English reading materials with pictures in which the topics the topics are related to their socialcultural environment. Last, the score 3.1 showed that the students agreed that they liked th activity to answer the comprehension questions after reading a text.

Tabel 6: The Result of Need Analysis in

Terms of Students' Learning Need

\begin{tabular}{|c|c|c|c|}
\hline No & Statements & $\begin{array}{c}\text { Sco } \\
\text { re }\end{array}$ & $\begin{array}{c}\text { Level of } \\
\text { agreement }\end{array}$ \\
\hline 1 & $\begin{array}{l}\text { I have ever learned to } \\
\text { read the reading rext } \\
\text { about my } \\
\text { sociocultural } \\
\text { environment }\end{array}$ & 1.8 & Fairly agree \\
\hline 2 & $\begin{array}{l}\text { The topic of English } \\
\text { reading text related to } \\
\text { my sociocultural } \\
\text { environment is } \\
\text { important to learn }\end{array}$ & 3.1 & Agree \\
\hline 3 & $\begin{array}{l}\text { It is easier for me to } \\
\text { understan the English } \\
\text { reading text whose } \\
\text { topics is related to my } \\
\text { sociocultural } \\
\text { environment }\end{array}$ & 3.8 & $\begin{array}{l}\text { Strongly } \\
\text { agree }\end{array}$ \\
\hline 4 & $\begin{array}{l}\text { I like to learn the } \\
\text { reading text about the } \\
\text { ecotourism places in } \\
\text { Medan }\end{array}$ & 3.8 & $\begin{array}{c}\text { Strongly } \\
\text { agree }\end{array}$ \\
\hline 5 & $\begin{array}{l}\text { I like to learn the } \\
\text { reading ttext about the } \\
\text { historical places in } \\
\text { Medan }\end{array}$ & 3.5 & Agree \\
\hline 6 & $\begin{array}{l}\text { I like to learn the } \\
\text { reading ttext about the } \\
\text { historical event in } \\
\text { Medan }\end{array}$ & 3.5 & Agree \\
\hline 7 & $\begin{array}{l}\text { I like to learn the } \\
\text { reading text about the } \\
\text { legend from Medan }\end{array}$ & 3.6 & $\begin{array}{l}\text { Strongly } \\
\text { agree }\end{array}$ \\
\hline 8 & $\begin{array}{l}\text { I like to learn the } \\
\text { reading text with the } \\
\text { picture whose topic is } \\
\text { related to my } \\
\text { sociocultural } \\
\text { environment }\end{array}$ & 3.3 & Agree \\
\hline 9 & $\begin{array}{l}\text { I like the reading } \\
\text { activity when we must } \\
\text { answer the question } \\
\text { related the text } \\
\text { provided }\end{array}$ & 3.1 & Agree \\
\hline
\end{tabular}

Step 2. Designing the Materials
The English reading materials are develop based on the data obtain from the previous steps. The materials writing follow the principles of developing materials based on local content.

Step 3. Validating by Experts

In order to produce the good, reliable and valid English reading materials, it is important to confduct the validation step. The validation is do by the expert judgement. The expert must the following criteria: 1) having good knowledge in education; 2) having good knowledge in ESP; 3) having good knowledge in English language learning. To determine the experts, purposive by BSNP (2011) are used as the guidance. The criteria include the content, language, process, layout.

There are two steps in this steps in this stage-validation process and final revision of the reading materials.

1) Validation

In validating the develop English reading materials, the experts judgement are used. The materials are validate in terms of their content, language, process, and the layout. The instrument used to validate the materials are questionnaire consisting a number statements.

Tabel 7: The Score Of Expert Judgement for English Reading Materials

\begin{tabular}{|c|c|c|c|c|c|}
\hline \multirow[t]{2}{*}{ No } & \multirow[t]{2}{*}{ Aspects } & \multicolumn{3}{|c|}{$\begin{array}{c}\text { Expert 1 } \\
\text { (Lecturers) }\end{array}$} & \multirow[t]{2}{*}{$\overline{\mathbf{\Sigma}} \mathbf{1}$} \\
\hline & & A & $\mathrm{B}$ & $\mathrm{C}$ & \\
\hline 1 & Content & 30 & 36 & 26 & \\
\hline 2 & Language & 20 & 22 & 18 & \\
\hline 3 & Presentation & 15 & 8 & 12 & \\
\hline 4 & Graphic & 20 & 13 & 18 & \\
\hline Total & & 85 & 79 & 74 & 79,3 \\
\hline
\end{tabular}

\begin{tabular}{|l|l|l|l|l|l|}
\hline No & \multicolumn{1}{|c|}{ Aspects } & \multicolumn{3}{|c|}{$\begin{array}{c}\text { Expert 2 } \\
\text { (Teachers) }\end{array}$} & $\overline{\mathbf{\Sigma} 2}$ \\
\hline & & A & B & C & \\
\hline 1 & Content & 32 & 35 & 40 & \\
\hline 2 & Language & 20 & 22 & 20 & \\
\hline 3 & Presentation & 13 & 12 & 15 & \\
\hline 4 & Graphic & 15 & 20 & 18 & \\
\hline Total & & 80 & 89 & 93 & $\mathbf{8 7 , 3}$ \\
\hline
\end{tabular}




\begin{tabular}{|c|c|c|c|c|c|}
\hline \multirow[t]{2}{*}{ No } & \multirow[t]{2}{*}{ Aspects } & \multicolumn{3}{|c|}{$\begin{array}{c}\text { Expert 3 } \\
\text { (Students) }\end{array}$} & $\bar{\Sigma} 3$ \\
\hline & & A & $\mathrm{B}$ & $\mathrm{C}$ & \\
\hline 1 & Content & 36 & 40 & 40 & \\
\hline 2 & Language & 24 & 24 & 22 & \\
\hline 3 & Presentation & 12 & 15 & 13 & \\
\hline 4 & Graphic & 20 & 18 & 20 & \\
\hline Total & & 92 & 97 & 95 & 94,6 \\
\hline
\end{tabular}

Tabel 8: The Score Of Expert Judgement for English Reading Materials

\begin{tabular}{|c|c|c|c|c|}
\hline No & $\overline{\mathbf{\Sigma}} \mathbf{1}$ & $\bar{\Sigma} 2$ & $\bar{\Sigma} 3$ & Total \\
\hline Total & $\mathbf{7 9 , 3}$ & 87,3 & 94,6 & 261,2 \\
\hline Average & & & & $\begin{array}{c}\frac{=\bar{\Sigma} 1+\bar{\Sigma} 2+\bar{\Sigma} 3}{2} \\
\frac{79,3+87,3+9}{\frac{4,6}{2}} \\
=87,06\end{array}$ \\
\hline
\end{tabular}

The result of experts' judgement was 87,06 . It belonged to good category based on Dirgeyasa (2011), since the range pf percentage was (70-89). It meant the materials were in "Good" category.

In addition, the experts were not only asked to give their evaluation, but also give their comments and suggestions about developed materials. Their comments were about the weakneses of the materials and suggestions to improve the developed materials. The following table was the description of the experts' feedback. The result of expert's judgement comments and suggestions were presented bellow:

Tabel 9: The Result of Experts Judgement's Comments and Suggestions

\begin{tabular}{|l|l|l|l|l|}
\hline $\begin{array}{l}\text { N } \\
\text { o }\end{array}$ & Aspects & Experts $_{1}$ & Experts $_{2}$ & Experts $_{3}$ \\
\hline 1 & Content & $\begin{array}{l}1 . \quad \text { Add } \\
\text { more tasks } \\
\text { or } \\
\text { exercises } \\
2 . \quad \text { Add } \\
\text { more } \\
\text { explain } \\
\text { the } \\
\text { materials }\end{array}$ & $\begin{array}{l}\text { Add } \\
\text { exercise } \\
\text { s }\end{array}$ & $\begin{array}{l}\text { No } \\
\text { revisions }\end{array}$ \\
\hline 2 & Language & $\begin{array}{l}\text { No } \\
\text { revisions }\end{array}$ & $\begin{array}{l}\text { No } \\
\text { revision } \\
\text { son }\end{array}$ & $\begin{array}{l}\text { No } \\
\text { revisions }\end{array}$ \\
\hline 3 & $\begin{array}{l}\text { Presentati } \\
\text { on }\end{array}$ & $\begin{array}{l}\text { No } \\
\text { revisions }\end{array}$ & $\begin{array}{l}\text { No } \\
\text { revision } \\
\text { s }\end{array}$ & $\begin{array}{l}\text { No } \\
\text { revisions }\end{array}$ \\
\hline 4 & Graphic & $\begin{array}{l}1 . \\
\text { more Add }\end{array}$ & $\begin{array}{l}\text { Make the } \\
\text { No } \\
\text { revisions }\end{array}$ \\
\hline
\end{tabular}

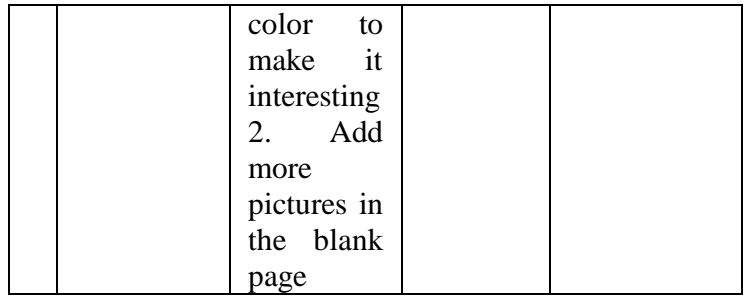

2) Final Revision

After getting feedback from the experts, the English reading materials were revised and written into the final draft.

\section{Conclusions}

After analyzing the data, the conclusions were drawn as the following:

1. Generally, the existing reading materials were less relevant with the needs of students at SMAN 10 Medan. In terms of topic, the materials were less relevant wih the studentts' sociocultural environment background which then made the students had less motivation in learning English.

2. The English reading materials needed by students were the materials in which the topics were appropriate to students' sociocultural environment background. Some topics like "Besween Island", "Maimoon Palace", "The Great Mosque", "Tjong A Fie Mansion", "The London Sumatra Building (Lonsum), "Lubuk Emas". "Putri Hijau" were considered as the most appropriate to develop as it representted the characteristics of Medan.

3. The materials were developed based on the local content in Medan. Some pinciples of local content based-materials development were used in writing the materials. They were identifying the basic competences of English reading for grade ten students, English reading basic competences for grade $\mathrm{X}$ students, writing the reading texts with the tasks or exercises related to each topics. The result of this research was a course book which consisted of 3 genres. Each genre consisted of 2 texts with the tasks or exercises. The developed materials had been validated by three experts. The score gotten from experts' judgement was 87,06 in which could be categorized as "good". It meant that the materials were appropriate 
for the grade $\mathrm{X}$ students of SMAN 10 Medan.

\section{Acknowledgement}

The writer would be like to thank and convey the deepest gratitude to Dr. Kammer Sipayung, M.Pd.,as the first consultant.

\section{REFERENCES}

Bandar Standar Nasional Pendidikan.

(2011). Pedoman Penyusun Kurikulum

Tingkat Satuan Pendidikan Jenjang Pendidikan Dasar dan Menengah. Jakarta: Depdiknas.

Dar, F. 2012. Textbook Material and Their

Succesful Application in The Classroom: Implication for Language Development. Journal of Educationaland Instructional Studies in The World,Journal, Vol.2.

Dirgeyasa, I Wy. 2011. Bahan Ajar Menulis Bahasa Inggris untuk Tujuan KhususESP Maritime English Berbasis Genre. Jakarta: Program Pascasarjana Universitas Negeri Jakarta.

Hutchinson, T. \& Waters, A. 1987. English for Specific Purposes. Cambridge: University Press.

Sipayung, K. T., Lubis, S., Setia, E., \& Silalahi, R. 2018. The Impact of Coherence Shift on the Acceptance of Translation of the Textbook,,Principles of Language Learning and Teaching'. Language \& Translation, 6(3), 121-129.

Maryono. 2016. The implementation of schools' policy in the development of the local content curriculum in primaryschools in Pacitan, Indonesia. Educational Research and Reviews. Vol. 11, No.8.

Tampubolon, S., \& Rajagukguk, D. (2016). The Effect of Synthesizing Strategy on Students' Reading Comprehension at SMA Serdang Murni Lubuk

Pakam. Reading, 2017. 